\title{
Rare Brazilian Sideneck Turtle
}

\section{R.A. Mittermeier, A.G.J. Rhodin, R. da Rocha e Silva, and N. Araujo de Oliveira}

In 1976 one of the authors saw a pet turtle which he recognised to be Phrynops hogei. This was remarkable because hitherto the type specimen, first described in 1967, was the only one known to scientists. However, since 1976 three other live animals have been seen, and also eight museum specimens. From the new information the authors conclude that the range of the species is small, and also that the type locality was wrongly given. They think the turtle may well be endangered, and suggest a captive breeding programme for its conservation.

The sidenecked turtles of the family Chelidae, which occur in South America and Australia-New Guinea, include several bizarre and well-known chelonians, such as the South American matamata Chelus fimbriatus and the Australian snake-necked turtle Chelodina longicollis. Nine genera are currently recognised, five of them from Australia-New Guinea - Chelodina, Emydura, Elseya, Pseudemydura, Rheodytes - and four from South America - Chelus, Phrynops, Platemys, Hydromedusa - but the number of species is uncertain. The South American genus Phrynops, sometimes called 'toad-headed turtles', is the least known chelid group and, at the same time, the most diverse and complex taxonomically. Although eleven taxa are now recognised, ${ }^{23}$ our studies indicate that several of the known species are poorly defined and that a number of species, including both described and undescribed forms, are quite rare, very restricted in range, and possibly endangered.

Al/ sideneck turtles protect the head and neck by turning the head sideways within the shell, as the photo above of Phrynops hogei shows. 
One of the rarest is Phrynops hogei until recently known only from the type specimen, now in Frankfurt's Senckenberg Museum. The purpose of this paper is to discuss its status and range, and to report the discovery of four live individuals.

Phrynops hogei was described in 1976 by the late Robert Mertens, a German herpetologist, ${ }^{1}$ on the basis of a single large specimen said to be from the Rio Pequeno in the state of São Paulo, Brazil, and collected by an Instituto Butantan expedition. Mertens found it in one of the snake enclosures on the Institute's grounds in São Paulo. He named it after the Brazilian herpetologist, Dr A.R. Hoge, who worked for the Instituto Butantan, and presented the specimen to the Senckenberg Museum.

In the course of revising the South American chelid turtles (Rhodin and Mittermeier, in prep.), we have discovered eight more museum specimens, and have also found four live ones in two private collections in Brazil. All the newly identified muse um specimens come from the Rio Paraiba drainage in the state of Rio de Janeiro and the adjacent southern margin of the state of Minas Gerais. One of the live individuals, a male measuring $221 \mathrm{~mm}$, was obtained by da Rocha in 1976 from a local person who kept it as a pet. It had been captured by a fisherman in the Campos area, also in the Paraiba drainage, but no further information was available, and attempts to obtain additional specimens from the same area were unsuccessful. The other three live specimens - two females measuring $340 \mathrm{~mm}$ and $232 \mathrm{~mm}$ in carapace length and one male measuring $343 \mathrm{~mm}$ - are all from a small area near the mouth of the Rio Itapemirim in the state of Espirito Santo. One da Rocha obtained in March 1980 from a local hunter; the other two were seen by Mittermeier in a private zoo in the grounds of Fazenda Ataliba, a large farm to the east of Highway BR-101, on a side road to Itapemirim.

On the basis of this new material, we believe that the range of $P$.hogei can be defined as low-lying areas under $500 \mathrm{~m}$ elevation in the Rio Paraiba drainage of Rio de Janeiro and southern Minas Gerais, north into coastal Espirito Santo at least as far as the Rio Itapemirim. The type locality, the Rio Pequeno near the city of Saro Paulo, is separated from the nearest locality in the Paraiba drainage by some $300 \mathrm{~km}$ of terrain over $500 \mathrm{~m}$ elevation, and presents something of a problem. Moreover, it is part of the inland drainage of the Rio Tiete and the Rio Paraná, whereas the other localities are all in the coastal drainages of the Paraiba and the Itapemirim. Since the type specimen discovered by Mertens was not tagged by the Instituto Butantan when released into the snake pit, it may well have been confused with other turtles in the same enclosure. So although we cannot be certain, it is likely that the type locality is wrong and that $P$. hogei does not occur in Sáo Paulo.

$P$. hoge $i$ should be listed in the Red Data Book as a rare species, and it may well be endangered. Its range is one of the smallest of any South American chelid, and it is quite rare within the restricted area that it inhabits. Furthermore, the Rio Paraiba, which is the major water source for the state of Rio de Janeiro, is being polluted in many areas; several tributaries have run dry, and siltation has resulted from increased erosion in zones of extensive deforestation.

Since nothing is known of the population dynamics, habitat requirements or local distribution of $P$. hogei, and since it probably occurs at low densities throughout most or all of its range, it would be very difficult to locate a suitable 


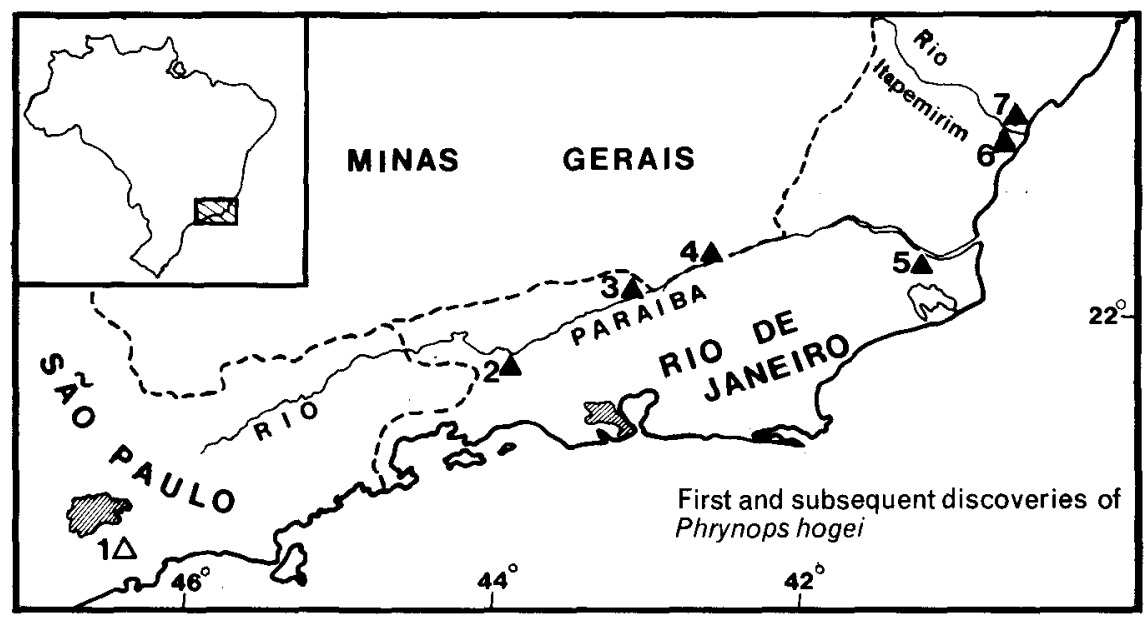

reserve site for it - even in the highly unlikely event that the Brazilian Government could be convinced of the need for a rare turtle reserve. We, therefore, feel that the best solution for this species would be to initiate a captive breeding programme and, if possible, an ecological study to learn more about it in the wild. Such a programme is being proposed as part of the Global Conservation Strategy currently being developed by the IUCN/SSC Freshwater Turtle Specialist Group.

A number of other South American chelids - e.g. Phrynops rufipes and $P$. dahli -are also quite rare and possibly endangered and will be discussed in later papers.

\section{Acknowledgments}

This paper is Misc. Contribution No.1 of the IUCN/SSC Freshwater Turtle Specialist Group. RAM's studies were partly funded by the World Wildlife Fund US and AGJR was partly funded by the American Philosophical Society. Our thanks to Isabel Constable for preparing the map.

\section{References}

1. MERTENS, R. 1967. Bemerkenswerte Susswasserschildkröten aus Brasilien. Senck. Biol. 48, $71-82$.

2. PRITCHARD, P.C.H. 1979. Encyclopedia of Turtles. TFH Publ., Hong Kong.

3. WERMUTH, H., and R. MERTENS 1977. Liste der rezenten Amphibien und Reptilien, Testudines, Crocodylia, Rynchocephalia. Tierreich 100, 1-174.

Dr Russell A. Mittermeier, World Wildlife Fund-US, Connecticut Avenue, NW, Washington DC 20009; and Dept. of Anatomical Sciences, Health Sciences Center, SUNY, Stony Brook, New York 11794, USA.

\section{Sri Lanka's New National Park}

Sri Lanka's promotion of the 10-sq-mile Lahugala Sanctuary to a National Park is particularly important because the new park is a link between the Ruhunu and Galoya National Parks. Ranjen Fernando writes that 'the surroundings of the Lahugala Tank withstand even the most severe drought, and are the feeding grounds for hundreds of elephants in July and October when rivers and waterholes are almost dry'. 